\title{
Expert concept mapping study on mobile learning
}

Citation for published version (APA):

Börner, D., Glahn, C., Stoyanov, S., Kalz, M., \& Specht, M. (2010). Expert concept mapping study on mobile learning. Campus-Wide Information Systems, 27(4), 240-253. https://doi.org/10.1108/10650741011073789

DOI:

$10.1108 / 10650741011073789$

Document status and date:

Published: 01/01/2010

Document Version:

Peer reviewed version

Document license:

CC BY-NC-ND

Please check the document version of this publication:

- A submitted manuscript is the version of the article upon submission and before peer-review. There can be important differences between the submitted version and the official published version of record. People interested in the research are advised to contact the author for the final version of the publication, or visit the DOI to the publisher's website.

- The final author version and the galley proof are versions of the publication after peer review.

- The final published version features the final layout of the paper including the volume, issue and page numbers.

Link to publication

\section{General rights}

Copyright and moral rights for the publications made accessible in the public portal are retained by the authors and/or other copyright owners and it is a condition of accessing publications that users recognise and abide by the legal requirements associated with these rights.

- Users may download and print one copy of any publication from the public portal for the purpose of private study or research.

- You may not further distribute the material or use it for any profit-making activity or commercial gain

- You may freely distribute the URL identifying the publication in the public portal.

If the publication is distributed under the terms of Article 25fa of the Dutch Copyright Act, indicated by the "Taverne" license above, please follow below link for the End User Agreement:

https://www.ou.nl/taverne-agreement

Take down policy

If you believe that this document breaches copyright please contact us at:

pure-support@ou.nl

providing details and we will investigate your claim.

Downloaded from https://research.ou.nl/ on date: 26 Apr. 2023 


\title{
Expert Concept Mapping Study on Mobile Learning
}

\begin{abstract}
Purpose

The presented paper introduces concept mapping as a structured participative conceptualization approach to identify clusters of ideas and opinions generated by experts within the domain of mobile learning. Utilizing this approach the paper tries to contribute to a definition of key domain characteristics by identifying the main educational concepts related to mobile learning.
\end{abstract}

\section{Design/methodology/approach}

A short literature review points out the attempts to find a clear definition for mobile learning as well as the different perspectives taken. Based on this an explorative case study was conducted, focusing on the educational problems that underpin the expectations on mobile learning. Using the concept mapping approach the study identified these educational problems and the related domain concepts. The respective results were then analyzed and discussed.

\section{Findings}

The chosen approach produced several means to interpret the experts' ideas and opinions, such as a cluster map illustrating and structuring substantial accordances. These means help to gain new insights on the emphasis and relation of the core educational concepts of mobile learning. The core educational concepts of mobile learning identified are: "access to learning", "contextual learning", "orchestrating learning across contexts", "personalization", and "collaboration".

\section{Originality/value}

The paper is original as it uses a unique conceptualization approach to work out the educational problems that can be addressed by mobile learning and thus contributes to a domain definition based on identified issues, featured concepts, and derived challenges. In contrast to existing approaches for defining mobile learning, the presented approach relies completely on the expertise of domain experts.

\section{Introduction}

So far there have been lots of attempts to define mobile learning, such as "learning that happens when the learner takes advantage of learning opportunities offered by mobile technologies" (O'Malley et al., 2003). The perspectives taken are either technocentric (like in the given example), consider the mobility of the learners, or rest upon the anytime/anywhere paradigm of existing content (Winters, 2006; Taylor, 2006). Each of these different perspectives is extensively discussed in the literature (Sharples, 2006; Traxler, 2009), but by now there is no generally accepted definition, nor an agreement on which perspective to consider finding one. Especially the technocentric perspective is highly controversial as the underlying 
development of mobile technologies is continuously progressing, making the attempted definitions highly unstable (Traxler, 2009).

A more promising way towards a theory of mobile learning (Sharples et al., 2005) seems to be the focus on the clarification of significant issues (Sharples, 2006), research challenges (Arnedillo-Sánchez et al., 2007), case studies (Kukulska-Hulme \& Traxler, 2007), or motivational or affective aspects (Jones et al., 2006). All these attempts contribute to a definition of key characteristics for mobile learning and sharpen the picture of what constitutes mobile learning rather then finding a precise definition. Traxler (2009) even suggests replacing the question 'what is mobile learning?' by the questions 'what is learning in the mobile age?' or 'what is mobile learning?' focusing more on the educational part of the domain. Following this suggestion we decided to conduct an explorative case study (Krathwohl, 1993; Yin, 1994) within the mobile learning domain that is not taking one of the perspectives mentioned earlier. Instead, the focus was set on the educational problems that underpin the expectations on mobile learning, while at the same time trying to find an adequate conceptualization of these problems. Therefore the following research questions have been defined:

1. What are the educational problems that mobile learning is trying to solve?

2. Which problem clusters can be identified and how are they emphasized?

3. How are the different problem areas related within the overall research domain of mobile learning?

In the following sections we will introduce the applied method, analyze and evaluate the results, and finally discuss the findings and their relevance for the domain of mobile learning.

\section{Method}

To answer the formulated research questions, the presented study implements the concept mapping approach that has been initially described by Trochim (1989a, b). This method has already been applied in several studies (Stoyanov \& Kirschner 2004; Wopereis, Kirschner, Paas, Stoyanov \& Hendriks, 2005). It provides a structured participative conceptualization approach to identify clusters of ideas and opinions generated by experts for a given domain aspect. The collected data is then analyzed via multidimensional scaling (Kruskal \& Wish, 1978; Davison, 1983) and hierarchical cluster analysis (Anderberg, 1973; Everitt, 1980). The result is a set of visual maps representing the generated idea and opinion statements as well as emerging statement clusters and thus important domain concepts. The method consists of several phases to prepare the collection of data and finally collect the data, each of which is described in the following sections.

\subsection{Preparation}

The initial phase of the method has three objectives: defining an initial focus or trigger statement for stimulating the generation of ideas and opinions, selecting key dimensions for rating the generated statements, and selecting the participants. 
Derived from the first research question the following trigger statement has been chosen: "The educational problem that mobile learning tries to solve is...". Based on the experiences of previous studies (Stoyanov \& Kirschner 2004; Wopereis, Kirschner, Paas, Stoyanov \& Hendriks, 2005), "importance" and "feasibility" were selected as respective key dimensions. These qualitative dimensions emphasize different aspects of the practices within the domain. The importance dimension refers to the relevance of an educational problem within the mobile learning context. The feasibility dimension refers to the potential of mobile learning for contributing to a sufficient solution for the related educational problem.

Finally the participants were selected from the member list of the International Association for Mobile Learning (IAMLearn, 2009). In total 32 international acknowledged domain experts have been invited to participate in the study. The invitees represented different stakeholder groups within the mobile learning domain, ranging from industry via research to educational practitioners. 20 out of the 32 invited experts accepted the invitation to participate in the study. Given to the international distribution of the participants, the communication as well as the data collection has been conducted entirely online via e-mail messages.

\subsection{Procedure}

The procedure to collect the data consisted of two phases: generation of idea and opinion statements and structuring the generated statements. Due to the characteristics of the method, the participants were actively involved in both phases of the data collection process. The phases are described in greater detail in the following sections.

\section{Generation of Statements}

In the first phase of data collection the participants were asked via e-mail to generate ideas and opinions on the previously defined trigger statement. The participants were instructed to simply reply to the e-mail message and include their identified educational problems as short bullet point statements underneath the trigger statement. The participants were free to generate as many statements as they wanted to. Although no direct control could be imposed on this process the participants were requested to describe exactly one educational problem in each statement and if possible limit the generation process to 10 minutes.

During this first phase, 11 experts generated 70 statements elaborating on the given focus in form of the trigger statement. Sighting the list of generated statements revealed an issue that needed to be solved before going on with the next phase. Almost each participant used an own structure to describe the ideas and opinions, which complicated the comparison of the statements. Therefore the statements were restructured into grammatically correct sentences and simultaneously revised for spelling mistakes. In doing so another issue was revealed, as some statements described more than one specific idea. To resolve the issue the relevant statements were taken apart and again restructured into grammatically correct sentences. Finally all the statements were compared to eliminate obvious duplicates, resulting in a list of 82 unique statements (e.g. "Maintaining continuity of learning across 
settings, such as between classrooms and museums on school field trips.") that could be used for the next phase.

\section{Structuring of Statements}

In the second phase all participants were asked to structure the statements that were collected during the first phase. The participants were contacted no matter weather they generated statements in the first phase or not. The structuring of the statements involved two independent steps: grouping the statements based on their perceived similarity in meaning and the rating of the statements. In order to collect as much information as possible from the participants while reducing the communication overhead, the two steps were combined using a single e-mail message. To ease the process for the participants three documents were attached to each message. One provided the complete list of all unique statements. The other two documents were used to record the results of the grouping and rating. The participants were asked to perform the structuring of the statements within two weeks. 9 experts participated in the structuring phase, grouping and rating the statements that were previously generated.

\section{Step A: Grouping}

In the first step the participants were asked to group the statements based on their similarity in meaning. The participants were asked to copy the statements from one document containing all statements into a second document containing a prepared form with empty group containers. The participants were informed that they should place all statements into one group only, while each group should contain statements that were similar in meaning to each other. The instructions emphasized that the similarity must focus on the content of the statement and not on importance or feasibility of the statement. If a statement in the participants' opinion was unrelated to the other statements or stood alone as a unique idea, they were allowed to put this statement in its own group. In any case they were neither allowed to create arbitrary groups such as "misc" or "junk" groups. Again the experts were free to create as many groups as they liked, suggesting that in most cases using 10 to 20 groups should work out well. When finished the participants were asked to create a label for each group that described the included statements. In total, the experts created 111 groups with an average of 12 groups per expert.

\section{Step B: Rating}

After grouping the statements the experts were asked to rate all statements in a third document. Each statement had to be rated on the key dimensions "importance" and "feasibility" on a 5-point Likert-scale. For importance the quantitative value 1 meant the statement described a less important educational problem that mobile learning is trying to solve and 5 meant the statement described a highly important educational problem. Respectively, for feasibility the quantitative value 1 meant solving the described educational problem through mobile learning is not feasible and 5 meant it is feasible to solve the problem through mobile learning. 


\section{Results}

\subsection{Data Analysis}

To analyze the collected data the concept mapping approach proposes statistical data analysis techniques to map and then cluster the problem statements. Additionally the average ratings for each problem statement and the respective problem clusters are calculated and can be incorporated in the resulting visualizations for further interpretation. In the presented study all required calculations and visualizations for the analyses were accomplished using the spreadsheet application Microsoft ${ }^{\circledR}$ Exce ${ }^{\circledR}$ version 12.2.4 (Microsoft Corporation, 2007) and the open source software environment for statistical computing R version 2.11.0 (R Development Core Team, 2010).

The concept mapping approach facilitates a nonmetric multidimensional scaling analysis (Trochim, 1989a) to map the relation between the statements. In the present study, the statements were mapped onto a twodimensional space, although multidimensional scaling can be applied across multiple dimensions. Trochim suggests the use of two dimensions, as the resulting bivariate distribution of points on the map is easier to visualize and interpret. Hence, the basis of the multidimensional scaling is a twodimensional symmetric matrix of similarities of all problem statements. This matrix includes the correlations between the statements based on the expert grouping of the statements. For any two statements 1 is added to the respective intersection point within the matrix, whenever an expert placed the two statements in the same group. The result of the multidimensional scaling is a point map representing the Euclidian distance between the statements based on their similarity. Each point on the map represents a problem statement.

In order to group the statements on the map into clusters of statements, representing important domain concepts, the resulting point map is then used as input for a hierarchical clustering analysis, based on Ward's algorithm for cluster analysis (Trochim, 1989a). This technique isolates the conceptual relationships across statements as they are positioned on the point map obtained from the multidimensional scaling. The difficulty here is to identify a reasonable number of clusters. The concept mapping approach leaves this task open to the judgment and interpretation of the analyst.

Consequently for the presented study the optimal number of clusters was determined through minimizing the cluster-size difference of the largest and the smallest cluster and maximizing the size of the smallest cluster. After identifying the clusters they were manually labeled. The labels were derived from a list of group labels linked with the cluster and the statements within the cluster. Ideally the group labels provided by the experts converged towards a common domain concept represented by the cluster. If this was not the case, a keyword analysis at statement level was used to find a suitable label. The result of the hierarchical cluster analysis is a cluster map representing the emerging statement clusters and thus important domain concepts. In addition to the points of each problem statement, the map includes the convex hull of the problem clusters. This allows the analysis and interpretation of the relations between the single clusters as well as the associated statements. 


\subsection{Problem Cluster Analysis}

As stated, the data analysis techniques were used to map the problem statements, identify, and label the problem clusters. The clusters represent the overarching domain concepts related to the educational problems addressed by mobile learning. Figure 1 shows the problem cluster map of the presented study.

\section{Figure 1 - Problem cluster map}

The complete result data set including all problem clusters and statements can be found in Table 1 in the Appendix. The following 7 problem clusters covering 82 problem statements were identified:

(1) Access to learning: The cluster covers 15 statements that are mainly related to the challenges of enabling learning in a mobile society. This includes educational problems that are related to flexible learning, including just-in-time learning, equal access to education and learning, and locationbased learning. The cluster also covers remote learning and accessibility aspects.

(2) Limitations for learning: 9 statements are included in the cluster. The statements cover challenges related to organizational and educational problems of educational institutions that result from different perceptions of the knowledge society in general and mobile technologies specifically among educators and learners. This also includes the problems of using of mobile technologies in formal learning scenarios.

(3) Contextual learning: The cluster includes 18 statements that highlight the relation between learning and the context in which the learning takes place. The cluster covers individual aspects of situated learning, learning in context, and learning across contexts. Furthermore environmental aspects are included, such as making use of environmental affordances and a stronger interaction with the environment where the learning takes place.

(4) Collaboration: 5 statements are included in the cluster. The statements cover challenges that are related to collaboration, sharing learning resources, and problems related to social interaction, such as difficulties of building a community during learning.

(5) Personalization: The cluster includes 8 statements. The statements range from educational problems with self-directed learning to mass-customization of learning and reflect the potential of mobile learning to support personal learning processes and engage learners.

(6) Orchestrating learning across contexts: 14 statements are included in the cluster, which deals with problems related to current educational practices. The cluster is strongly related to the contextual learning cluster, but focuses more on the organizational aspects that mobile learning can support.

(7) Technology and technology adoption: The cluster covers 13 statements. These statements address challenges related to the technological characteristics of mobile devices and factors of their adoption, including costeffectiveness, usability, and user-acceptance. 


\subsection{Problem Emphasis Analysis}

A detailed analysis of the average rating of the problem statements indicates the experts' opinion about which statements refer to important and feasible educational problems related to mobile learning. Furthermore this analysis also allows estimating the importance and feasibility of the 7 problem clusters as domain concepts. The complete result data set including all problem clusters and statements with attached means can be found in Table 1 in the Appendix.

Starting with the problem statement emphasis, a statement was considered as important or feasible if the mean was at least 3.5 based on the 5 point Likert-scale rating. An average rating of 3.5 indicates that the experts rated the statement mostly as important or feasible. By taking both rating key dimensions into account the statements can be mapped into four quadrants. Figure 2 shows the quadrants and the mapped statements without identifying the actual statements.

Figure 2 - Statement rating map

The first quadrant contains those statements that are relevant on both dimensions, with a high average rating on importance and feasibility. Thus included statements refer to the most relevant educational problems addressed by mobile learning. In the experts' opinion 34 statements are located in this quadrant. The majority of the statements are related to the clusters "contextual learning" (13 statements), "access to learning" (11 statements), and "orchestrating learning across contexts" (5 statements). The highest rated statements within these clusters are also included in the quadrant. The remaining statements are related to the clusters "technology and technology adoption" (3 statements) and "personalization" (2 statements).

The second quadrant contains statements with a high average rating on importance but low average rating on feasibility. The 13 statements in this quadrant can be considered to refer to important educational problems addressed by mobile learning, while sufficient solutions might go beyond the scope of mobile learning. The statements in this cluster are related to the clusters "contextual learning" (4 statements), "access to learning" (2 statements), "collaboration" (2 statements), "orchestrating learning across contexts" (2 statements), and "technology and technology adoption" (2 statements). The remaining statement is related to the "personalization" cluster.

The third quadrant contains statements with low average ratings on both dimensions. 34 statements fall in this quadrant. These statements are considered to refer to educational problems that are not specifically related to mobile learning in the experts' opinion. The majority of statements in this quadrant are related to the clusters "limitations for learning" (9 statements) and "technology and technology adoption" (8 statements). The remaining statements are related to the clusters "orchestrating learning across contexts" (6 statements), "personalization" (5 statements), "collaboration" (3 statements), "access to learning" (2 statements), and "contextual learning" (1 statement). 
The fourth quadrant contains statements with a high average rating on feasibility but low average rating on importance. The quadrant contains only a single statement that refers to a side educational problem to which mobile learning can offer solutions. This statement is related to the "orchestrating learning across contexts" cluster.

Table 2 - Highest emphasized problem statements

\begin{tabular}{|l|c|c|}
\hline \multicolumn{1}{|c|}{ Problem Statement } & \multicolumn{1}{c|}{ Mean } \\
\hline \multicolumn{1}{|c|}{ Importance } & Feasibility \\
\hline \multicolumn{1}{|c|}{} & \\
\hline $\begin{array}{l}\text { 20 Actively participate in learning activities outside of formal } \\
\text { educational settings and facilities. }\end{array}$ & 4,44 & 4,11 \\
\hline $\begin{array}{l}\text { 17. Access to learning resources and learning opportunities } \\
\text { without the restrictions of location, time and cumbersome } \\
\text { equipment or facilities. }\end{array}$ & 4,44 & \multirow{2}{*}{4,00} \\
\hline $\begin{array}{l}\text { 59 Access to information when and where it is required, } \\
\text { through 'just in time' browsing of relevant information, and } \\
\text { information push to support learning in context. }\end{array}$ & 4,44 & 3,89 \\
\hline 41 Easing access to educational opportunities. & 4,56 & 3,67 \\
\hline $\begin{array}{l}\text { 53 Connect learning across contexts, including between formal } \\
\text { and informal settings. }\end{array}$ & 4,44 & 3,78 \\
\hline $\begin{array}{l}\text { 16 Ability to discover and experiment in own context. } \\
\text { 25 Mobility of the learner. }\end{array}$ & 4,44 & 3,67 \\
\hline $\begin{array}{l}\text { 30 The provision of access to knowledge in the context in } \\
\text { which it is applied. }\end{array}$ & 4,00 & 4,11 \\
\hline 79 Including learners from rural areas. & 4,56 & 3,56 \\
\hline $\begin{array}{l}\text { 61 Accessibility of information in relevant everyday life and } \\
\text { work situations. }\end{array}$ & 4,22 & 3,89 \\
\hline
\end{tabular}

Concerning the importance and feasibility of the problem clusters, the average ratings of all problem statements included in a cluster needed to be considered. This analysis revealed that "access to learning" is rated as the most important cluster in the experts' opinion, followed by the clusters dealing with "contextual learning", "orchestrating learning across contexts", "personalization", "collaboration", "technology and technology adoption", and finally "limitations for learning". Thus in the experts' opinion the accessibility and contextualization of learning and education are the most important domain concepts that mobile learning can facilitate. The respective clusters also contain the majority of problem statements and as stated the highest rated statements, listed in Table 2 in the Appendix. Regarding the rated feasibility the emphasis is similar. The clusters of "contextual learning" and "access to learning" are rated as the most feasible domain concepts that mobile learning can facilitate, followed by the clusters dealing with "orchestrating learning across contexts", "collaboration", "personalization", "technology and technology adoption", and finally "limitations for learning".

\section{Discussion}

Based on the experts' emphasis the used concept mapping approach identified the most important educational problems that can be addressed by mobile learning. The identified problems are all related to the three main domain concepts "access to learning", "contextual learning", and "orchestrating learning across contexts", while most of them are related to the 
concept "access to learning". This clearly reflects the claim on mobile learning to enable learning across context, facilitating and exploiting the mobility of the learners. The most emphasized issues mainly discuss learning activities and opportunities outside of formal settings, better contextualized and situated learning support, stronger connection between informal and formal settings, and the inclusion of rural and remote learners. Among others these issues indicate the most important current and future use cases for the implementation of mobile learning scenarios. On the other hand the experts considered issues related to technologies and their adoption and usage by teachers, learners and other stakeholders as less important to be addressed by mobile learning. The respective problems are mostly related to the domain concepts "technology and technology adoption" and "limitations for learning".

The emphasis given by the experts does also provide valuable recommendations. Educational institutes and organizations can draw direct conclusions about the core themes of future research agendas and implementation plans out of the study results. To provide an example, the most relevant problem statement within the "Contextual learning" cluster is "Connect learning across contexts, including between formal and informal settings." The statement is positioned in the first quadrant of the statement rating map shown in Figure 2, as it got a high average rating on importance and feasibility. In the experts' opinion facilitating learning across contexts is one of the most important challenges in the domain of mobile learning. At the same time there seem to be sufficient solutions to cope with that challenge. The conclusion that can be drawn is that these solution need to be implemented on a short term.

Contrary to this example is the problem statement "Enable learning through distributed conversation across contexts." covered in the same cluster. The statement is positioned in the second quadrant of the statement rating map with a high average rating on importance but low average rating on feasibility. So in the experts' opinion this challenge is also quite important, but it seems that there are no feasible solutions yet. Examining the statement clarifies this emphasis. To enable a distributed conversation across contexts is related to research in the field of e.g. computer supported cooperative learning. Even if the complex technology mainly coming from the field of mobile and ubiquitous computing is there, it still needs to be utilized in the learning context, which requires additional research efforts also within the field of mobile learning.

In addition to the valuable emphasis, the approach also produced a problem cluster map representing the mobile learning domain concepts based on the similarity of the problem statements identified. The main concepts that characterize the educational challenges mobile learning has to cope with are "access to learning", "contextual learning", "orchestrating learning across contexts", "personalization", and "collaboration". The minor domain concepts are "technology and technology adoption" and "limitations for learning". The produced map can also be used to relate the emerging problem clusters within the overall domain.

The map shows that the clusters "access to learning" and "contextual learning" appear to be independent domain concepts, as they are individually 
positioned beyond the centre. The other clusters seem to be more closely related and positioned near to the centre. The mapping shows that the "orchestrating learning across contexts" cluster is the central concept within the domain. This indicates that orchestration is the link between the different concepts within the domain of mobile learning. Both the "collaboration" and the "technology and technology adoption" cluster are positioned in close proximity to the central concept, illustrating that the covered problem statements need to be considered when dealing with orchestration and vice versa. The clusters of "personalization" and "limitations for learning" are positioned a little bit further away from the central concept and thus do not need to be considered equally when orchestrating learning through mobile learning. The same applies for the distant clusters "access to learning" and "contextual learning".

Focusing on the spatial extend of the single problem clusters, reveals that educational problems covered by the clusters "access to learning", "contextual learning", and "orchestrating learning across contexts" are in most cases only loosely related to each other. The mentioned clusters cover a wide problem space. In contrast the other clusters, especially "technology and technology adoption", cover a relatively narrow problem space with closely related problem statements. On the one hand this underlines that the main domain concepts cover a diversity of educational problems and it might be useful to put more effort on a more finely granulated distinction in order to make further analyses easier to handle. On the other this fact shows that these concepts are still a major point of discussion and there is no agreement on a clear definition related to mobile learning.

\section{Conclusion}

The presented expert concept mapping study provides new insights on mobile learning and the educational problems that underpin the expectations on it. Especially the identified domain concepts contribute to the discussion about the key characteristics of mobile learning, while clarifying the major educational problems that can be addressed by mobile learning. Still the paper outlines only the major findings of the conducted study. The data collected as well as the results obtained from the concept mapping approach allow further profound analyses on single or multiple domain concepts or specific educational issues and their correlation to others. Furthermore the results can also be used to provide guidelines for upcoming discussions on the theoretical and technical developments within the domain of mobile learning. These aspects will be addressed in future work.

\section{Acknowledgement}

As part of a subordinated small-scale study on location-based and contextual mobile learning, the presented study was conducted in cooperation with the Learning Sciences Research Institute (University of Nottingham) within the framework of the STELLAR Network of Excellence. STELLAR is a $7^{\text {th }}$ Framework Programme project funded by the European Commission, grant agreement number: 231913 (http://www.stellarnet.eu).

STELLAR represents the effort of the leading institutions and projects in European Technology-Enhanced Learning (TEL) to unify the diverse 
community. STELLAR's instruments act upon the backbone of an interlocking set of 3 Grand Research Challenge actions, themed as Connecting Learners, Orchestration and Context (STELLAR, 2009).

\section{References}

Anderberg, M.R. (1973), Cluster analysis for applications, Academic Press, New York, NY.

Arnedillo-Sánchez, I., Sharples, M. \& Vavoula, G. (Eds.) (2007), Beyond Mobile Learning Workshop, Trinity College Dublin Press, Dublin.

Davison, M.L. (1983), Multidimensional Scaling, John Wiley and Sons, New York, NY.

Everitt, B. (1980), Cluster Analysis (2nd Edition), Halsted Press, New York, NY.

IAMLearn (2009), "The International Association for Mobile Learning", available at: http://mlearning.noe-kaleidoscope.org/ (accessed 11 March 2010)

Jones, A., Issroff., K, Scanlon, E, Clough, G and McAndrew, P. (2006), "Using mobile devices for learning in Informal Settings: Is it Motivating?", in Proceedings of IADIS International conference Mobile Learning Dublin, IADIS Press, Barcelona, pp. 251-255.

Krathwohl, D. (1993), Methods of educational and social science research, Longman, New York, NY.

Kruskal, J.B. \& Wish, M. (1978), Multidimensional scaling, Sage Publications, Beverly Hills, CA.

Kukulska-Hulme, A. \& Traxler, J. (2007), "Design for Mobile and Wireless Technologies", in Beetham, H. \& Sharpe, R. (Eds.), Rethinking Pedagogy for the Digital Age, Routledge, London, pp. 180-192.

Microsoft Corporation (2007), "Microsoft ${ }^{\circledR}$ Excel $^{\circledR} 2008$ for Mac", Microsoft Corporation, Santa Rosa, CA.

O’Malley, C., Vavoula, G., Glew, J., Taylor, J., Sharples, M. \& Lefrere, P. (2003), "Guidelines for learning/teaching/tutoring in a mobile environment", available at: http://www.mobilearn.org/download/results/guidelines.pdf (accessed 11 May 2010).

R Development Core Team (2010), "R: A language and environment for statistical computing", R Foundation for Statistical Computing, Vienna.

Sharples, M., Taylor, J., \& Vavoula, G. (2005), "Towards a theory of mobile learning", in Proceedings of mLearn2005 - 4th World Conference on mLearning, 25-28 October 2005, Cape Town, South Africa, available at: http://www.mlearn.org.za/CD/papers/Sharples- Theory of Mobile.pdf (accessed 2 April 2010). 
Sharples, M. (2006), Big Issues in Mobile Learning, Kaleidoskop Network of Excellence, Mobile Learning Initiative, Nottingham.

STELLAR Network of Excellence (2009), "D1.1 The STELLAR Vision and Strategy Document", available at:

http://www.stellarnet.eu/repository/deliverable_repository_list/ (accessed 17 February 2010).

Stoyanov, S. \& Kirschner, P. (2004), "Expert concept mapping method for defining the characteristics of adaptive E-learning: ALFANET project case", Educational Technology Research and Development, 52 (2), pp. 41-54.

Taylor, J. (2006), "What are appropriate methods for evaluating learning in mobile environments? Evaluating Mobile Learning", in Sharples, M. (Ed.), Big Issues in Mobile Learning, Kaleidoskop Network of Excellence, Mobile Learning Initiative, Nottingham, pp. 26-28.

Traxler, J. (2009), "Learning in a Mobile Age", International Journal of Mobile and Blended Learning, 1(1), pp. 1-12.

Trochim, W. (1989a), "An introduction to concept mapping for planning and evaluation", in Trochim, W. (Ed.), A Special Issue of Evaluation and Program Planning, Pergamon Press, New York, NY, pp. 1-16.

Trochim, W. (1989b), “Concept mapping: Soft science or hard art?”, in Trochim, W. (Ed.), A Special Issue of Evaluation and Program Planning, Pergamon Press, New York, NY, pp. 87-110.

Winters, N. (2006), "What is Mobile Learning?", in Sharples, M. (Ed.), Big Issues in Mobile Learning, Kaleidoskop Network of Excellence, Mobile Learning Initiative, Nottingham, pp. 7-11.

Wopereis, I. G. J. H., Kirschner, P. A., Paas, F., Stoyanov, S., \& Hendriks, M. (2005), "Failure and success factors of educational ICT projects: A group concept mapping approach", British Journal of Educational Technology, 36, pp. 681-684.

Yin, R. (1994), "Case study research. Design and methods", Sage

Publications, Thousand Oaks, CA.

\section{Appendix}

Table 1 - Rating of problem clusters and statements

\begin{tabular}{|c|c|c|}
\hline Problem Cluster & \multicolumn{2}{|c|}{ Mean } \\
\hline Statement & Importance & Feasibility \\
\hline 1 Access to learning & 4.03 & 3.59 \\
\hline $\begin{array}{l}\text { 17. Access to learning resources and learning opportunities } \\
\text { without the restrictions of location, time and cumbersome } \\
\text { equipment or facilities. }\end{array}$ & 4,44 & 4,00 \\
\hline $\begin{array}{l}59 \text { Access to information when and where it is required, } \\
\text { through 'just in time' browsing of relevant information, and } \\
\text { information push to support learning in context. }\end{array}$ & 4,44 & 3,89 \\
\hline 41 Easing access to educational opportunities. & 4,56 & 3,67 \\
\hline
\end{tabular}




\begin{tabular}{|c|c|c|}
\hline 25 Mobility of the learner. & 4,00 & 4,11 \\
\hline 79 Including learners from rural areas. & 4,22 & 3,89 \\
\hline $\begin{array}{l}61 \text { Accessibility of information in relevant everyday life and } \\
\text { work situations. }\end{array}$ & 4,33 & 3,67 \\
\hline 9 Learning at anytime. & 3,89 & 4,00 \\
\hline 80 Developing third world countries' education. & 4,11 & 3,78 \\
\hline 8 Learning from any location. & 3,89 & 3,78 \\
\hline 11 Just in time information for immediate application. & 4,11 & 3,56 \\
\hline 1 Limited access by some learners in remote locations. & 3,67 & 3,89 \\
\hline $\begin{array}{l}51 \text { Enable learners in classroom settings to have equal access } \\
\text { to rich resources and computational tools to support } \\
\text { curriculum learning. }\end{array}$ & 3,89 & 3,22 \\
\hline 78 Including learners with disabilities. & 4,33 & 2,78 \\
\hline $\begin{array}{l}4 \text { Nomads who move from one location to the next while } \\
\text { learning. }\end{array}$ & 3,22 & 3,22 \\
\hline $\begin{array}{l}45 \text { Inequality of access to computers, learning resources and } \\
\text { teachers. }\end{array}$ & 3,33 & 2,44 \\
\hline 3 Contextual learning & 3.92 & 3.60 \\
\hline $\begin{array}{l}53 \text { Connect learning across contexts, including between formal } \\
\text { and informal settings. }\end{array}$ & 4,44 & 3,78 \\
\hline 16 Ability to discover and experiment in own context. & 4,44 & 3,67 \\
\hline $\begin{array}{l}30 \text { The provision of access to knowledge in the context in } \\
\text { which it is applied. }\end{array}$ & 4,56 & 3,56 \\
\hline $\begin{array}{l}33 \text { Taking education out of classroom settings into meaningful } \\
\text { settings. }\end{array}$ & 4,00 & 3,89 \\
\hline $\begin{array}{l}39 \text { Interacting with your environment to achieve new } \\
\text { knowledge from it. }\end{array}$ & 4,22 & 3,67 \\
\hline $\begin{array}{l}50 \text { Under-utilization of potentially rich learning resources in } \\
\text { heritage sites, art collections and all sorts of other interesting } \\
\text { places. }\end{array}$ & 3,56 & 4,22 \\
\hline 73 Learning in context. & 4,00 & 3,78 \\
\hline 74 Learning across contexts. & 4,22 & 3,56 \\
\hline $\begin{array}{l}58 \text { Using technology to probe or to enrich understanding of the } \\
\text { natural environment, and annotating the environment for the } \\
\text { benefit of visitors. }\end{array}$ & 3,67 & 4,11 \\
\hline $\begin{array}{l}29 \text { The design of augmented contexts for development } \\
\text { problem to enable collaborative problem solving where } \\
\text { learners generate their own 'temporal context for } \\
\text { development'. }\end{array}$ & 3,89 & 3,78 \\
\hline 12 Learners cannot learn in context. & 3,88 & 3,63 \\
\hline 57 Making use of affordances of locations to support learning. & 3,88 & 3,63 \\
\hline $\begin{array}{l}55 \text { Enable enquiry-based learning in novel locations, through } \\
\text { novel locations, and about novel locations. }\end{array}$ & 3,89 & 3,44 \\
\hline 63 Contextualization of e-learning. & 3,67 & 3,56 \\
\hline $\begin{array}{l}56 \text { Making use of space and environment as a backdrop for } \\
\text { engaged spatial learning. }\end{array}$ & 3,67 & 3,22 \\
\hline $\begin{array}{l}70 \text { The worthwhileness of location-based and contextual } \\
\text { mobile learning. }\end{array}$ & 3,56 & 3,33 \\
\hline $\begin{array}{l}60 \text { Enable learning through distributed conversation across } \\
\text { contexts. }\end{array}$ & 3,78 & 2,78 \\
\hline 3 Insufficient real life experience in the learning process. & 3,22 & 3,22 \\
\hline 6 Orchestrating learning across contexts & 3.59 & 3.28 \\
\hline $\begin{array}{l}20 \text { Actively participate in learning activities outside of formal } \\
\text { educational settings and facilities. }\end{array}$ & 4,44 & 4,11 \\
\hline 24 Flexibility for the learner. & 4,00 & 3,89 \\
\hline $\begin{array}{l}54 \text { Maintaining continuity of learning across settings, such as } \\
\text { between classrooms and museums on school field trips. }\end{array}$ & 4,11 & 3,67 \\
\hline 62 Documenting real time experiences of learners. & 3,89 & 3,78 \\
\hline
\end{tabular}




\begin{tabular}{|c|c|c|}
\hline 37 Design suitable activities for the mobile learners. & 3,89 & 3,67 \\
\hline $\begin{array}{l}52 \text { Orchestrate new forms of classroom pedagogy that require } \\
\text { coordination of individual, small group and whole class activity. }\end{array}$ & 4,00 & 3,33 \\
\hline $\begin{array}{l}18 \text { Provision of opportunities to contribute to the } \\
\text { development/production of learning resources and course } \\
\text { content without the restrictions of location, time and } \\
\text { cumbersome equipment or facilities. }\end{array}$ & 4,00 & 2,89 \\
\hline $\begin{array}{l}47 \text { Blinkered, old-fashioned views about education stopping } \\
\text { when working lives begin. }\end{array}$ & 3,44 & 3,22 \\
\hline 40 Anything is a potential learning scenario. & 2,88 & 3,50 \\
\hline $\begin{array}{l}28 \text { Outside in, inside out problem, where cultural practices } \\
\text { involving new digital media can be brought into formal learning } \\
\text { institution, get enhanced inside the institution and in turn } \\
\text { feedback into the digital world at large. }\end{array}$ & 3,22 & 3,00 \\
\hline $\begin{array}{l}46 \text { Pressured, busy, fragmented, mobile lives leaving little } \\
\text { quality time for conventional, place-and-time-dependent } \\
\text { education. }\end{array}$ & 3,33 & 2,89 \\
\hline 64 Transfer of training. & 3,44 & 2,56 \\
\hline $\begin{array}{l}49 \text { Gaps (time lags) between traditionally scheduled learning } \\
\text { sessions, limiting achievement, teamwork and collaboration. }\end{array}$ & 3,11 & 2,56 \\
\hline $\begin{array}{l}31 \text { Refreshing the image and practice of institutional e- } \\
\text { learning. }\end{array}$ & 2,56 & 2,89 \\
\hline 5 Personalization & 3.46 & 3.13 \\
\hline 81 Engagement of the learner. & 4,44 & 3,56 \\
\hline 15 Not enough self-directed learning activities while learning. & 3,67 & 3,78 \\
\hline 75 Self-directed learning. & 3,89 & 3,11 \\
\hline $\begin{array}{l}23 \text { Finding new learning strategies that are suitable for the } \\
\text { challenges of, and embraces the opportunities of, the } \\
\text { knowledge and information age. }\end{array}$ & 3,33 & 3,11 \\
\hline $\begin{array}{l}43 \text { Students exhibit passivity, boredom, indifference, low } \\
\text { attention spans, and fail to complete their studies. }\end{array}$ & 3,44 & 2,78 \\
\hline 42 The perception that there is a lack of student engagement. & 3,11 & 2,89 \\
\hline 76 Learning with narratives. & 2,89 & 3,11 \\
\hline 77 Mass-customized learning. & 2,89 & 2,67 \\
\hline 4 Collaboration & 3.31 & 3.24 \\
\hline $\begin{array}{l}19 \text { Provision of opportunities to collaborate, share and publish } \\
\text { learning resources and course content without the restrictions } \\
\text { of location, time and cumbersome equipment or facilities. }\end{array}$ & 4,33 & 3,33 \\
\hline 65 Spontaneous collaboration in situated learning. & 3,67 & 3,33 \\
\hline 5 Lack of community building during learning. & 3,11 & 3,33 \\
\hline 7 Not enough collaboration between learners. & 2,89 & 3,44 \\
\hline $\begin{array}{l}10 \text { Learners not able to interact with experts from around the } \\
\text { world. }\end{array}$ & 2,56 & 2,78 \\
\hline 7 Technology and technology adoption & 3.32 & 3.05 \\
\hline $\begin{array}{l}36 \text { Make use of the affordable technologies that students have } \\
\text { access to. }\end{array}$ & 3,78 & 3,78 \\
\hline $\begin{array}{l}66 \text { Harness the fact that every student in every university owns } \\
\text { a sophisticated communications device. }\end{array}$ & 3,89 & 3,67 \\
\hline $\begin{array}{l}21 \text { Enhance teaching and learning within formal educational } \\
\text { settings and facilities through handheld technologies. }\end{array}$ & 3,78 & 3,44 \\
\hline $\begin{array}{l}72 \text { Get students to use their mobile devices constantly also in } \\
\text { education. }\end{array}$ & 3,67 & 3,56 \\
\hline $\begin{array}{l}34 \text { Helping educational institutions to offer learning aligned to } \\
\text { the students' ownership, experience \& use of technology. }\end{array}$ & 3,89 & 2,89 \\
\hline 69 Dealing with small screens and difficult data input. & 3,22 & 3,33 \\
\hline $\begin{array}{l}32 \text { Helping educational institutions understand the increasing } \\
\& \text { near-universal ownership, acceptance and use of mobile } \\
\text { devices across society. }\end{array}$ & 3,22 & 3,11 \\
\hline
\end{tabular}




\begin{tabular}{|c|c|c|}
\hline $\begin{array}{l}27 \text { Cost-effectiveness for the providers of teaching and } \\
\text { learning. }\end{array}$ & 3,33 & 2,89 \\
\hline 26 Cost-effectiveness for the learner. & 3,33 & 2,78 \\
\hline 71 Difficulties to reuse the products. & 3,11 & 2,56 \\
\hline $\begin{array}{l}38 \text { Assess learning experiences to be accountable for the } \\
\text { stakeholders. }\end{array}$ & 2,78 & 2,67 \\
\hline $\begin{array}{l}67 \text { Revolutionize mobile learning, as the iPhone has } \\
\text { revolutionized mobile telephony. }\end{array}$ & 2,75 & 2,38 \\
\hline $\begin{array}{l}68 \text { Make mobile learning a revenue stream for } \\
\text { telecommunication companies. }\end{array}$ & 2,44 & 2,56 \\
\hline 2 Limitations for learning & 3.23 & 2.80 \\
\hline $\begin{array}{l}22 \text { Finding new teaching methodologies that are suitable for } \\
\text { the challenges of, and embraces the opportunities of, the } \\
\text { knowledge and information age. }\end{array}$ & 3,44 & 3,22 \\
\hline $\begin{array}{l}2 \text { Lack of support to young learners, which have the mobile } \\
\text { technology. }\end{array}$ & 3,11 & 3,44 \\
\hline 14 Lack of ICT skills for the 21st century. & 3,33 & 3,22 \\
\hline $\begin{array}{l}82 \text { Transformation of traditional education according to the } \\
\text { needs of information society. }\end{array}$ & 3,44 & 2,67 \\
\hline $\begin{array}{l}48 \text { Traditionally ineffective instruction and low learner } \\
\text { performance in some subjects. }\end{array}$ & 3,44 & 2,56 \\
\hline $\begin{array}{l}6 \text { Low motivation of learners who are mobile technology } \\
\text { literate. }\end{array}$ & 3,11 & 2,78 \\
\hline 13 Teachers not comfortable using mobile technology. & 3,33 & 2,56 \\
\hline 44 Rigid assessment systems stifle creativity and innovation. & 3,44 & 2,33 \\
\hline 35 Perceptions of technologically impoverished provision. & 2,43 & 2,43 \\
\hline
\end{tabular}

